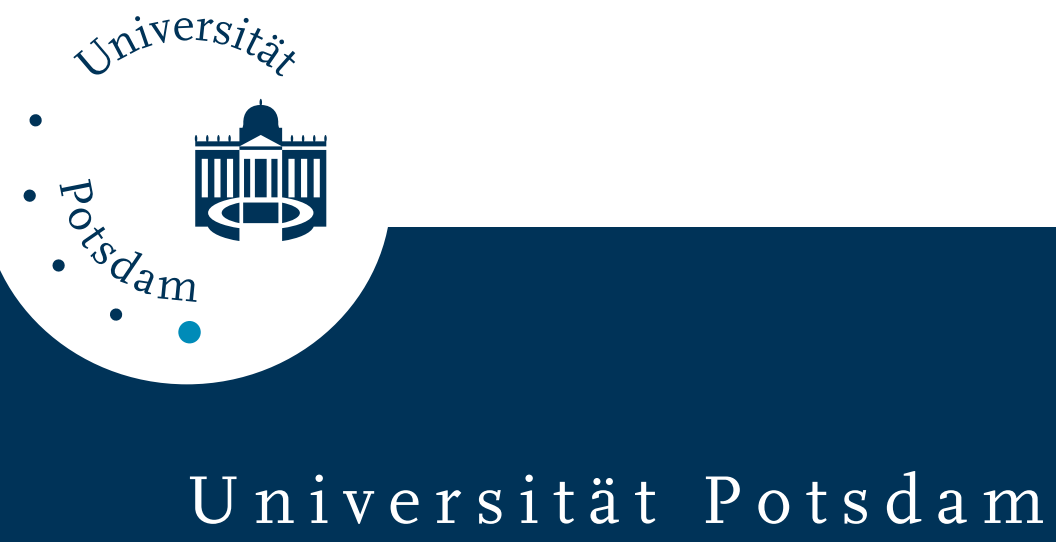

Andreas, Gardemann ; Gerhard, Püschel ; Kurt, Jungermann

\title{
Nervous control of liver metabolism and hemodynamics
}

first published in:

European Journal of Biochemistry 207 (1992), 2, S. 399-411

Postprint published at the Institutional Repository of the Potsdam University:

In: Postprints der Universität Potsdam

Mathematisch-Naturwissenschaftliche Reihe ; 164

http://opus.kobv.de/ubp/volltexte/2011/5134/

http://nbn-resolving.de/urn:nbn:de:kobv:517-opus-51346

Postprints der Universität Potsdam

Mathematisch-Naturwissenschaftliche Reihe ; 164 


\title{
Review
}

\section{Nervous control of liver metabolism and hemodynamics}

\author{
Andreas GARDEMANN, Gerd P. PÜSCHEL and Kurt JUNGERMANN \\ Institut für Biochemie, Georg-August-Universität Göttingen, Federal Republic of Germany
}

(Received March 3, 1992) - EJB 920292

Besides being a center of intermediary metabolism, a center of defense and a control center for the hormonal system, the liver acts as the glucose reservoir of the organism and, moreover, as an important blood reservoir, by taking up or releasing glucose and blood. The many diverse hepatic functions are controlled by the substrate concentrations in blood, the circulating hormone levels, the biomatrix and the autonomic hepatic nerves. In this review, the present knowledge on the metabolic and hemodynamic effects, the mechanism of action and the function of the hepatic nerves, as studied in the isolated perfused liver, are summarized.

\section{Effects of hepatic nerve stimulation}

In perfused rat liver, activation of the sympathetic liver nerves increases glucose and lactate release, urate and allantoin formation, decreases ketogenesis, urea release, ammonia uptake, xenobiotics conjugation, bile flow and bile acid secretion as well as oxygen utilization, and causes an overflow of noradrenaline into the hepatic vein. Furthermore, sympathetic stimulation decreases the flow and elicits an intrahepatic redistribution as well as a mobilization of blood by the closing of sinusoids. Activation of parasympathetic nerves enhances glucose utilization and causes re-opening of previously closed sinusoids. The actions of hepatic nerves are modulated by the hormones glucagon, insulin, adrenaline, noradrenaline, vasopressin and angiotensin.

\section{Extrahepatocellular signal chain of sympathetic nerve stimulation}

The release of noradrenaline from the nerve endings and all effects of electrical nerve stimulation are strictly dependent on the presence of extracellular calcium. Sympathetic nerves regulate the hepatic metabolism of carbohydrates and ketone bodies and the conjugation of xenobiotics directly via interaction with non-parenchymal and parenchymal liver cells. However, sympathetic nerves regulate metabolism of nitrogenous compounds indirectly via reduction of blood flow. Studies with adrenergic and prostanoid agonists and antagonists support the following mechanism. Noradrenaline, released from the nerve endings via $\alpha_{1}$-adrenergic receptors, directly interacts with periportal hepatocytes and also stimulates prostanoid formation in nearby non-parenchymal liver cells. Prostanoids, in turn, modulate metabolism in parenchymal cells. About $50 \%$ of the metabolic nerve effects in rat liver are mediated via signal propagation through gap junctions. By this mechanism, rat liver apparently compensates the scarce innervation of only a few parenchymal and non-parenchymal cells in the proximal periportal zone.

\section{Intrahepatocellular signal chain of sympathetic nerve stimulation}

Sympathetic nerve stimulation of the perfused rat liver causes an increase in the activity of glycogen phosphorylase and a decrease in the activity of glycogen synthase, but leaves the activity of pyruvate kinase unaltered; fructose 2,6-bisphosphate and cAMP are only slightly enhanced. Various studies strongly support the notion that the intracellular signal chain is propagated by production of inositol 1,4,5-trisphosphate and an increase in cytosolic calcium.

In conclusion, hepatic nerves, together with the hormonal system, are directly involved in the regulation of liver metabolism and hemodynamics.

Correspondence to A. Gardemann, Institut für Biochemie, GeorgAugust-Universität Göttingen, Humboldtallee 23, W-3400 Göttingen, Federal Republic of Germany

Fax: + 49-551-395960

Abbreviations. BM 13505, 4-[2-(4-chlorobenzenesulfonamide)ethyl] benzeneacetic acid; CGP $35949 \mathrm{~B}, N-\{3-[3-(4-a c e t y]-3-h y d r o x y-$ 2-propylphenoxy)propoxy]-4-chlorine-6-methyl-phenyl\}-1H-tetrazo- le-5-carboxamide sodium salt; $\mathrm{TXA}_{2}$, thromboxane $\mathrm{A}_{2}$ analog U46619.

Enzymes. Calmodulin-dependent myosin light-chain kinase (EC 2.7.1.37); cyclooxygenase (EC 1.14.99.1); glycogen phosphorylase (EC 2.4.1.1); glycogen phosphorylase kinase (EC 2.7.1.38); glycogen synthase (EC 2.4.1.11); phospholipase $\mathrm{A}_{2}$ (EC 3.1.1.4); pyruvate kinase (EC 2.7.1.40); 5'-lipoxygenase (EC 1.13.11.34); protein kinase $\mathrm{C}$ (EC 2.7.1.37); tyrosine aminotransferase (EC 2.7.1.38). 
Table 1. Functions of the liver.

\begin{tabular}{lll}
\hline Main function & Subfunction & Purpose \\
\hline Center of metabolism & energy supply of the body & $\begin{array}{l}\text { glucose uptake and release } \\
\text { ketone body production } \\
\text { urea production } \\
\text { amino acid uptake and release } \\
\text { lipid processing } \\
\text { plasma protein synthesis and degradation } \\
\text { bile formation }\end{array}$ \\
& biosynthesis and biodegradation & $\begin{array}{l}\text { xenobiotic metabolism } \\
\text { phagocytosis and biochemical elimination of foreign } \\
\text { macromolecules and macromolecular aggregates } \\
\text { elimination of tumor cells } \\
\text { inactivation and elimination of hormones and me- } \\
\text { diators } \\
\text { synthesis and release of (pro)hormones and mediators } \\
\text { Blood reservoir }\end{array}$ \\
& & $\begin{array}{l}\text { active blood storage } \\
\text { passive blood storage }\end{array}$ \\
\hline
\end{tabular}

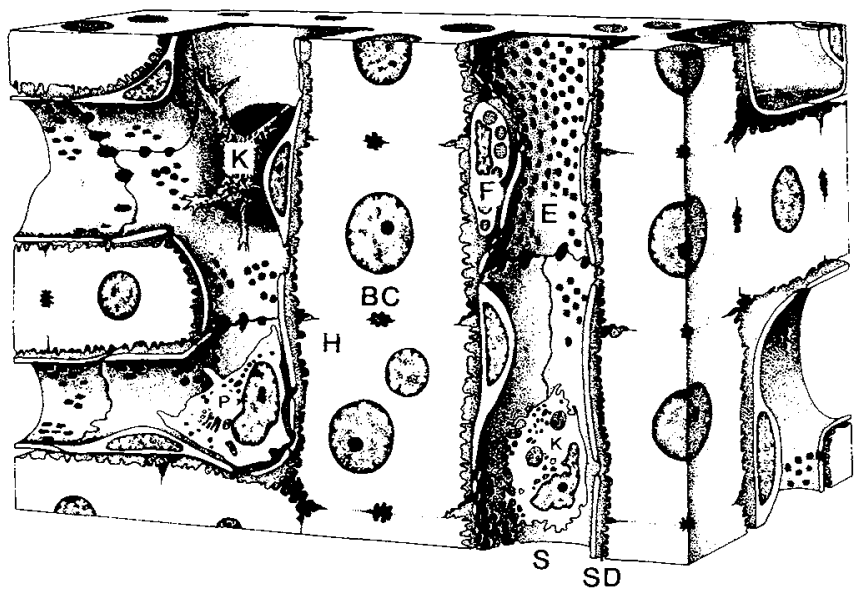

Fig. 1. Schematic drawing of liver tissue. The parenchyma consists of liver cell plates formed by adjoining hepatocytes $(\mathrm{H})$. Blood flow through the sinusoids (S) formed by the fenestrated endothelial cells (E) which are sorrounded by perisinusoidal or fat storing cells (F). Kupffer cells $(\mathrm{K})$ and pit cells $(\mathrm{P})$ bulge into the sinusoidal lumen from the endothelial cells. The space between the endothelial lining and the liver cell plates is the space of Disse (SD), in which the ectoskeleton of the liver composed of collagen, fibronectin, different glycoproteins and proteoglycans are located. $\mathrm{BC}$, bile canaliculi. Taken from Sasse, D., Spornitz, U. M. \& Maly, I. P. (1992) Liver Architecture, Enzyme, in the press.

The liver is the center of intermediary metabolism, a center of defense, a control center for the hormonal system and a blood reservoir (Table 1). The many diverse hepatic functions are provided by parenchymal and non-parenchymal cells (Fig. 1) and are regulated by substrate concentrations in blood, circulating hormone levels, autonomic hepatic nerves and the biomatrix. Moreover, the parenchymal cells can be under the control of the non-parenchymal cells and vice versa. Finally, the zonal heterogeneity of the parenchymal cells $[1$, 2] and the heterogeneity of the non-parenchymal cell population [3, 4], comprising endothelial cells, resident macrophages (Kupffer cells), perisinusoidal cells (lipocytes, fat storing cells, Ito cells) and large granular lymphocytes (pit cells) (Fig. 1) are important factors contributing to the various liver functions and their regulation.

It is the aim of this review first to give a short introduction into the anatomy of hepatic innervation and a brief overview on in vivo studies of hepatic nerve functions, then to summarize the present knowledge about the metabolic and hemodynamic effects, the mechanism of action and the function of the hepatic nerves as studied in the isolated perfused liver.

\section{Anatomy of hepatic innervation}

This section provides only a short overview of hepatic innervation. Additional and more detailed information is avaiable in other publications [5-11].

\section{Extrinsic innervation}

Nerves innervating the liver include afferent and efferent, sympathetic, parasympathetic and peptidergic components (Fig. 2). The hepatic sympathetic fibers are derived from the splanchnic nerves, the parasympathetic fibers from the vagus nerves. Splanchnic, vagal and sometimes also phrenic nerves enter the liver primarily with the hepatic artery, portal vein and bile duct. Some fibers are not associated with the hepatic vasculature and enter the liver via the lesser omentum or the hepatic vein. Sympathetic and parasympathetic nerves form two separate, but communicating, plexuses; the anterior plexus around the hepatic artery is composed of fibers originating from the celiac ganglion and anterior vagus, the posterior plexus around the portal vein and bile duct is formed by fibers from the celiac ganglion and right vagus.

The sensory afferent nerves were estimated to represent up to $90 \%$ of the fibers of the abdominal vagus and about $50 \%$ of sympathetic fibers in the splanchnic nerve [11]. Afferent vagal fibers project primarily to the left nodose ganglion, then to the medial portion of the left solitary nucleus [12]. Afferent splanchnic fibers also project to the left solitary nucleus [13]. Efferent sympathetic nerves originate in the ventromedial hypothalamus and parasympathetic fibers in the lateral hypothalamus [14] (Fig. 2). 


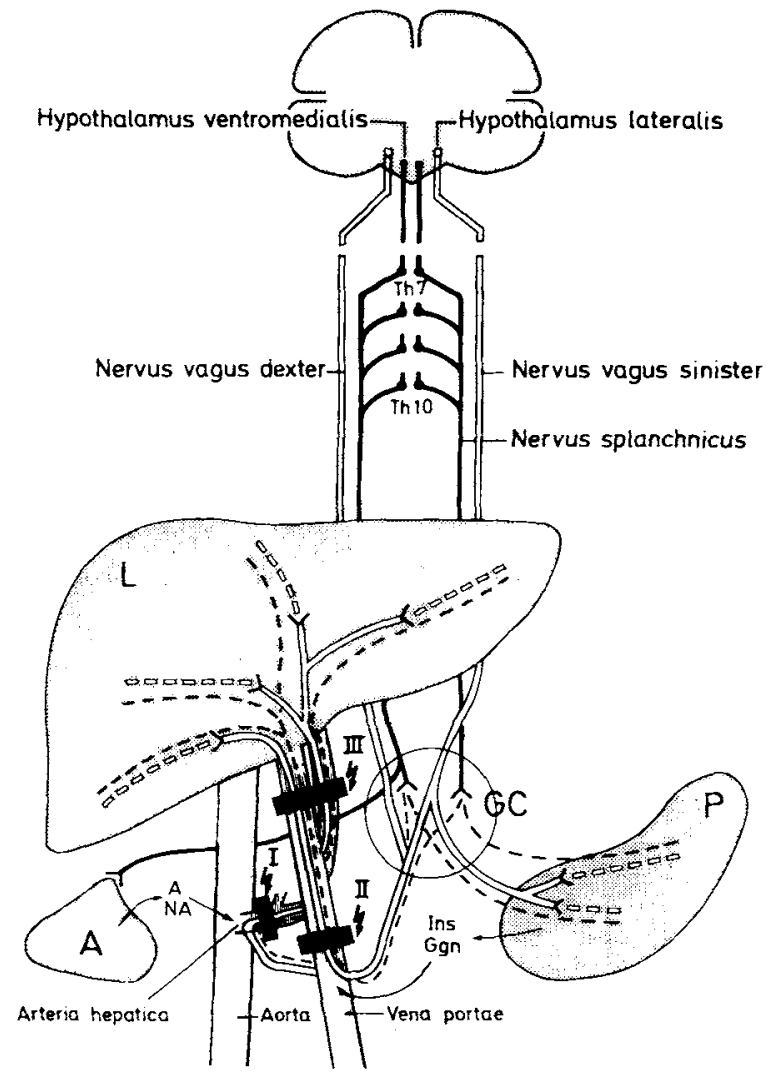

Fig. 2. Scheme of efferent liver innervation and sites of neurostimulation. (I) Stimulation of the arterial plexus at the common hepatic artery. (II) Stimulation of the portal plexus at the mesenteric vein. (III) Joint stimulation at the hepatic artery and portal vein in the liver hilus. L, liver; P, pancreas; A, adrenals; Ins, insulin; Ggn, glucagon; A, adrenaline; NA, noradrenaline; GC, ganglion coeliacum; Th7(10), seventh(tenth) thoracal segment of the splanchnic nerve.

\section{Intrinsic innervation}

Many intrinsic nerves of the liver are associated with the arterial and portovenous vasculature-forming plexuses in the adventitia and terminating on smooth muscle cells $[15,16]$. Nerve endings have also been demonstrated on Kupffer cells, fat-storing cells and the hepatocytes $[11,17]$. Whereas the density of the vascular innervation does not vary considerably [18], the extent and distribution of intralobular innervation exhibit remarkable interspecies variations $[15,18,19]$. In the guinea pig and tree shrew, nearly all hepatocytes possess nerve contacts [18], whereas in the rat only a few periportal hepatocytes are innervated $[18,19]$. The extent of the intrinsic innervation of the parenchymal cells seems to be inversely correlated to the number of signal-propagating gap junctions, since in livers of the tree shrew and guinea pig only a low density [15], but in rat liver [19] a high density of gap junctions has been demonstrated. Studies of primate liver [15] suggest that intralobular innervation is primarily, if not exclusively, monoaminergic. So far, a significant cholinergic innervation of the lobule has only been demonstrated in the guinea pig liver $[11,20]$. Besides an adrenergic and a cholinergic innervation a peptidergic innervation has also been found in livers of various species. Vasoactive intestinal peptide could be demonstrated in the hilar region, substance $P$ in the periportal area and neurotensin in the parenchymal region $[21,22]$. Neuropeptide
$\mathrm{Y}$ is apparently co-localized with noradrenaline in hepatic nerve terminals $[23,24]$ and was identified together with substance $P$ and calcitonin-gene-related peptide in nerve fibers around lymphatic capillaries in the interconnective tissue of rat liver [25]. The functions of the petidergic innervation of the liver have not been studied so far.

\section{In vivo studies on the role of hepatic nerves}

Many studies have been performed in living animals in order to assess the physiological role of the hepatic nerves. It is, however, far beyond the scope of this review to discuss these experiments in detail. They will be considered only briefly to provide a useful background to the studies with isolated perfused livers, reviewed in the next sections. More detailed reviews presenting the in-vivo data have been published recently $[7,11,26-28]$.

\section{Acute metabolic and hemodynamic regulation by efferent nerves}

Efferent sympathetic hepatic nerves work in the frequency range $2-20 \mathrm{~Hz}[29,30]$, the efferent parasympathetic fibers in the range $5-15 \mathrm{~Hz}$ [31]. It is not known whether a change in the frequency range of sympathetic nerves can alter the ratio in which colocalized substances in nerve endings like neuropeptide $\mathrm{Y}[23,24]$ can be released. The discharge rates of the nerves are regulated by the blood-glucose concentration via the central nervous system [11]; the frequency of parasympathetic nerves can be increased in vivo by taste stimulation [32].

Metabolism. Efferent sympathetic fibers, connected to the liver, have been stimulated either in the ventromedial hypothalamus $[33,34]$, preganglionically at the subdiaphragmatic splanchnic nerve [35-40] or postganglionically at the liver hilus $[41-46]$. Stimulation resulted in an increase in liver glycogen phosphorylase activity in rabbits [35] and an increase in blood glucose levels in anaesthetized dogs $[40,42,44]$, cats $[40,41,43,45]$, rabbits $[35,39,47]$, sheep [40], pig [40] and men [46], a decrease in hepatic oxygen consumption in cats [48] and an overflow of noradrenaline into the hepatic vein in dogs [42].

Efferent parasympathetic fibers connected to the liver have been stimulated either in the lateral hypothalamus [49] or preganglionically at the cervical left vagus nerve [41, 50]. Stimulation increased hepatic glycogen synthesis in rabbits $[50,51]$ and reduced hepatic glucose output in chemically sympathectomized cats [52].

Hemodynamics. Stimulation of the sympathetic splanchnic nerves reduced hepatic blood flow in cats and dogs $[48,53$, 54] and lowered the blood volume in the hepatic capacitance vessels, thereby replenishing the systemic circulation. These effects were antagonized by circulating adenosine and glucagon $[55,56]$. In cats, bile secretion was reduced by stimulation of the splanchnic nerve [57]. Stimulation of the hepatic branch of the vagus nerve opened previously closed sinusoids in the rat $[58,59]$.

\section{Chronic regulation by efferent nerves}

There is also evidence that liver nerves are involved, not only in short-term, but also in long-term metabolic regulation. Local removal of sympathetic fibers decreased hepatic cholesterol synthesis, whereas destruction of the parasympathetic fibers increased hepatic cholesterol synthesis in rats [60]. Selec- 
Table 2. Effects of stimulation of the arterial and portal nerve plexus on metabolism, perfusion flow, bile flow and noradrenaline overflow in perfused rat liver. Rat livers were perfused via the portal vein in the orthograde (O) or retrograde (R) direction with a Krebs-Henseleit bicarbonate buffer with (ERY) or without $(\mathrm{KH}) 30 \%$ (by vol.) erythrocytes containing $5 \mathrm{mM}$ glucose, $2 \mathrm{mM}$ lactate and $0.2 \mathrm{mM}$ pyruvate (GLP) and, where indicated, additionally with $0.2 \mathrm{mM} \mathrm{NH}_{3}$ plus $2 \mathrm{mM}$ ornithin (GLPN) or $0.75 \mathrm{mM}$ oleate (GLPO). When indicated, $10 \mu \mathrm{M}$ sodium-nitroprussiate (NP) or $20 \mu \mathrm{M}$ nifedipin (NI) were infused before the start of nerve stimulation. The arterial and portal plexuses were jointly stimulated in the liver hilus $(20 \mathrm{~Hz}, 2 \mathrm{~ms}, 20 \mathrm{~V})$ for $5 \mathrm{~min}$. Positive values indicate release or reduction of uptake; negative values indicate uptake or reduction of output. Values are means \pm SEM of $3-5$ experiments. Data are from $[74,77,79-84,97]$. Values for metabolism. are in $\mu \mathrm{mol} \cdot \min ^{-1} \cdot \mathrm{g}^{-1}$, for hemodynamics in $\mathrm{ml} \cdot \mathrm{min}^{-1} \cdot \mathrm{g}^{-1}$, for bile-acid secretion in $\mathrm{nmol} \cdot \mathrm{min}^{-1} \cdot \mathrm{g}^{-1}$, for $\operatorname{signal}$ propagation in pmol $\cdot \min ^{-1} \cdot \mathrm{g}^{-1}$ and for bile flow in $\mu \mathrm{l} \cdot \min ^{-1} \cdot \mathrm{g}^{-1}$.

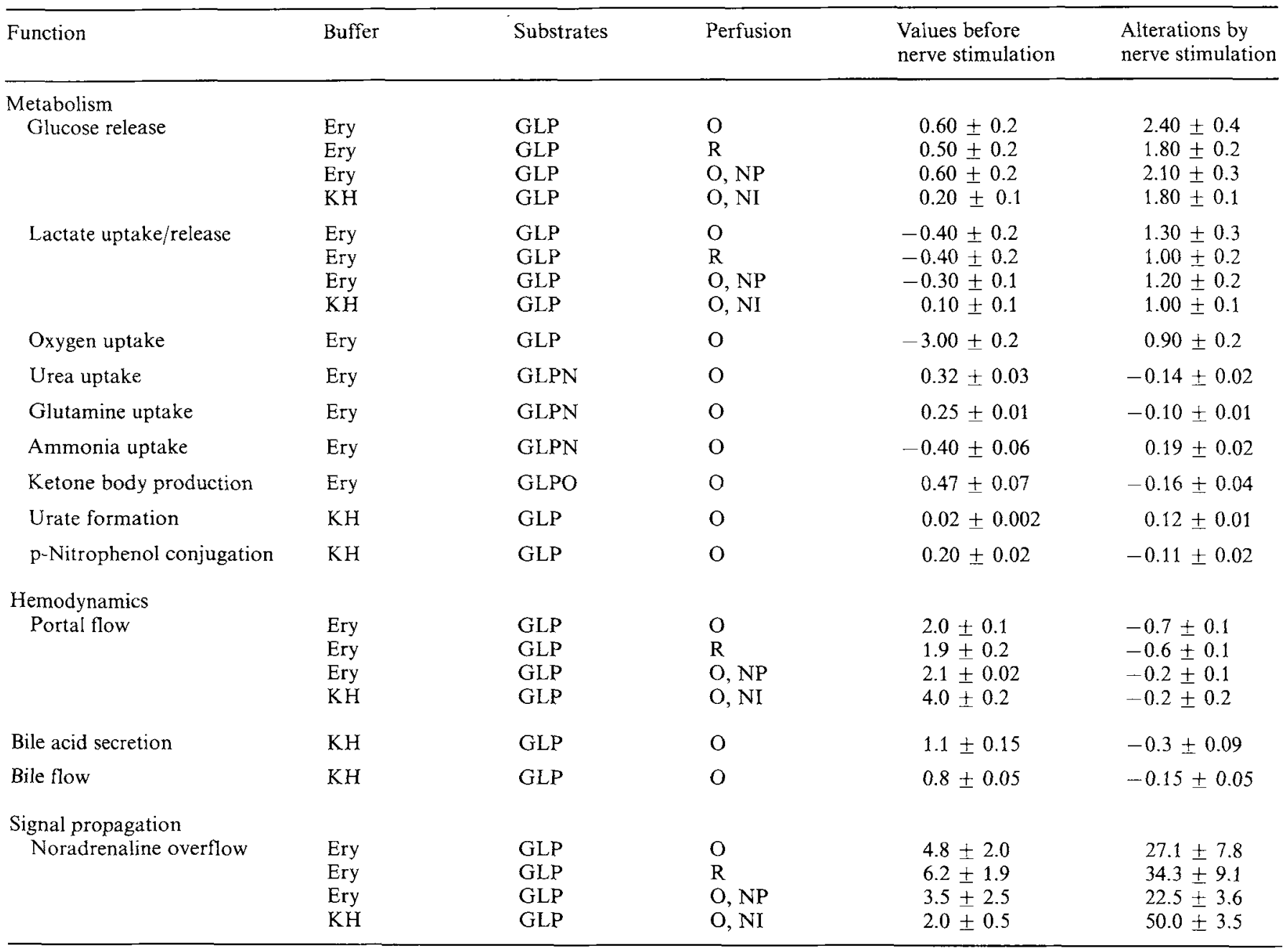

tive hepatic vagotomy abolished the day/night thythm of tyrosine aminotransferase [61] and reduced the cytochrome $P 450$ content [62] of the liver. Likewise, carbon tetrachloride-induced hepatic injury was aggravated by simultaneous stimulation of the ventromedial hypothalamus, causing an increased hepatic sympathicotonus [34]. Sympathetic denervation resulted in a hyperplasia of liver fibroblasts [63] that could be antagonized by infusion of adenosine. Denervated livers showed a compensatory hypersensitivity to glucagon [64] and noradrenaline [65].

\section{Communication with other organs via afferent nerves}

The importance of afferent hepatic nerves in the regulation of glucose homeostasis has been studied extensively by the group of Nijima $[25,26,66-69]$ and by others [70-72]. Glucose infusion into the portal vein decreased the discharge rate of hepatic vagal afferents [66-68], subsequently reduced the activity of the hepatic branch of efferent splanchnic nerve fibers [69] and the level of circulating catecholamines, increased the discharge rate of the efferent pancreatic branch of the vagus nerve [69] and thereby finally caused systemic hypoglycemia [70]. The stimulation of insulin secretion by intraperitoneal administration of glucose was abolished [71] and the stimulation of arginine was enhanced [72] by hepatic vagotomy. Electrical stimulation of the afferent branch of the hepatic vagus nerve decreased insulin secretion [69] in anesthetized rats. All these data provide evidence for a direct neural control of pancreatic and adrenal functions by glucose sensors in the liver.

\section{Effects of hepatic nerves in isolated perfused liver}

For studies on the importance of liver nerves in the regulation of hepatic metabolism and hemodynamics, rat livers were perfused either via the portal vein only with a pressure of about $2 \mathrm{kPa}$ [73], or simultaneously via both the hepatic artery with a high pressure of about $13 \mathrm{kPa}(20-40 \%$ of total 


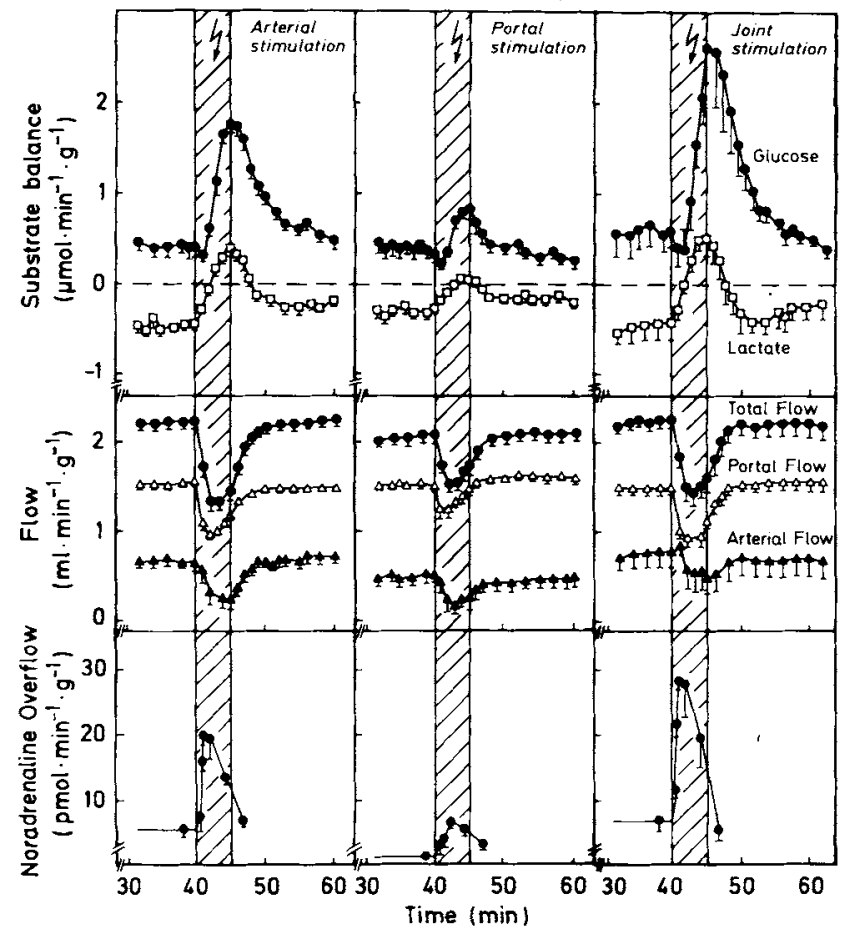

Fig. 3. Effects of separate and simultaneous stimulation of the arterial and portal nerve plexuses on glucose and lactate balance and on arterial, portal and total flow in the isolated perfused rat liver. Livers were perfused via the hepatic artery and portal vein with a Krebs-Henseleit bicarbonate buffer containing $30 \%$ (by vol.) erythrocytes, $5 \mathrm{mM}$ glucose, $2 \mathrm{mM}$ lactate and $0.2 \mathrm{mM}$ pyruvate. Hepatic nerves were stimulated $(7.5 \mathrm{~Hz}, 2 \mathrm{~ms}, 20 \mathrm{~V})$ separately at the arterial (Fig. 2, site I) and portal (Fig. 2, site II) plexus and jointly at both plexuses in liver hilus (Fig. 2, site III). Substrate balance is given by $\{$ [(concentration in hepatic vein $\left(\mu \mathrm{mol} \cdot \mathrm{ml}^{-1}\right) \times$ flow $\left.\left(\mathrm{ml} \cdot \mathrm{min}^{-1} \cdot \mathrm{g}^{-1}\right)\right]-[$ concentration in portal vein $\left(\mu \mathrm{mol} \cdot \mathrm{ml}^{-1}\right) \times$ portal flow $\left.\left(\mathrm{ml} \cdot \mathrm{min}^{-1} \cdot \mathrm{g}^{-1}\right)\right]+[$ concentration in hepatic artery $\left(\mu \mathrm{mol} \cdot \mathrm{ml}^{-1}\right) \times$ arterial flow $\left.\left.\left(\mathrm{ml} \cdot \min ^{-1} \cdot \mathrm{g}^{-1}\right)\right]\right\}$. A positive value indicates release, a negative value uptake. Values are means \pm SEM of seven experiments for glucose and lactate balance and three experiments for hemodynamics and noradrenaline overflow. More detailed informations are given in [75].

flow) and the portal vein with a low pressure of about $2 \mathrm{kPa}$ $(80-60 \%$ of total flow) [74].

\section{Metabolic effects of sympathetic nerves}

Although sympathetic, parasympathetic and other nerve fibers are activated by perivascular nerve stimulation, sympathetic actions clearly predominated [73-75]. Thus, in portally perfused rat livers, perivascular stimulation of the arterial and portal plexus increased glucose output and shifted lactate uptake to output [73], enhanced urate and allantoin formation [76] as well as glutathione efflux [77], decreased ketone body production [78], urea and glutamine formation as well as ammonia uptake [79], reduced $p$-nitrophenol conjugation [80], bile flow and bile acid secretion [81] and lowered oxygen uptake [82-84] (Table 2). In portally perfused mouse liver, stimulation of the hepatic nerves also increased glucose release [85].

In hepatic-artery-plus-portal-vein-perfused rat liver, single separate stimulation of only the arterial plexus at the common

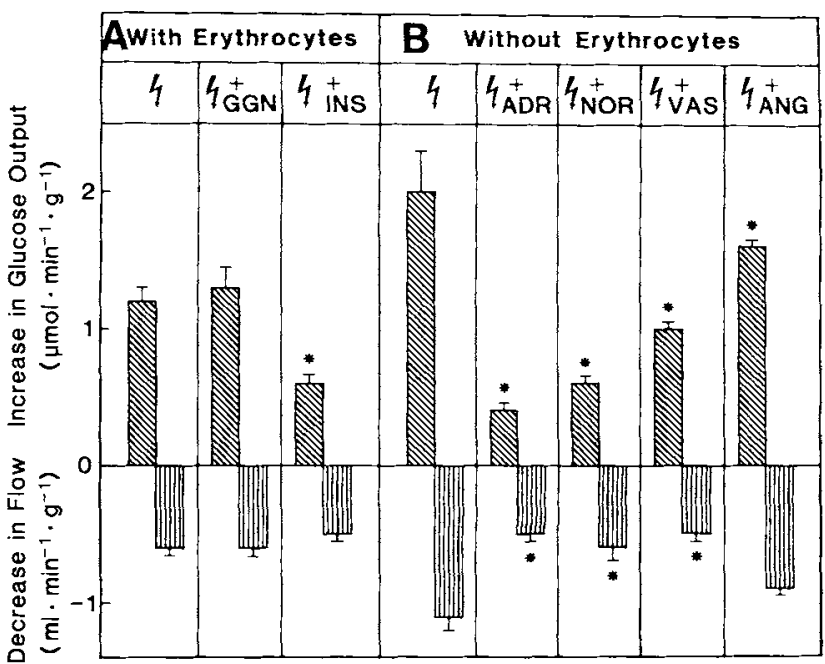

Fig. 4. Modulation by hormones of the nerve-stimulation-dependent alterations in glucose balance and perfusion flow in the isolated perfused liver. Perfusion of the liver via the portal vein with joint perivascular nerve stimulation (Fig. 2, site III). (A) The organ was perfused with the standard erythrocyte-containing medium (see Fig. 3); nerves were stimulated with $20 \mathrm{~Hz}, 2 \mathrm{~ms}, 20 \mathrm{~V}$ for $5 \mathrm{~min}$. When indicated, insulin (INS) and glucagon (GGN) were infused at 100 and $1 \mathrm{nM}$ concentration, respectively, before the start of nerve stimulation. (B) The organ was perfused with standard medium (see Fig. 3) without erythrocytes; nerves were stimulated with $10 \mathrm{~Hz}, 0.5 \mathrm{~ms}, 12 \mathrm{~V}$ for $2 \mathrm{~min}$. When indicated, adrenaline (ADR), noradrenaline (NOR), vasopressin (VAS) and angiotensin (ANG) were infused at 40, 100, 0.1 and $0.2 \mathrm{nM}$ concentration, respectively, before the start of nerve stimulation. Values are means \pm SEM of $3-5$ experiments each. Student's $t$-test for unpaired values; $* P<0.05$ for nerve stimulation versus nerve stimulation in the presence of hormone. Data are from [87-89].

hepatic artery caused $2-3$-fold greater metabolic changes in the glucose and lactate balance than stimulation of the portal plexus at the mesenteric vein (Fig. 3) [74]. The effects after single separate stimulation were additive to those after simultaneous separate stimulation, which in turn were the same as after joint stimulation of both plexuses in the liver hilus. The sympathetic actions on glucose and lactate balance, both in portal-vein-perfused [86] and in hepatic-artery-plus-portalvein-perfused [74] livers, were half-maximal at a frequency of around $5 \mathrm{~Hz}$, which is within the physiological range of frequencies of up to $20 \mathrm{~Hz}$ [29].

Interactions between the hormonal and nervous systems were studied in portal-vein-perfused liver (Fig. 4). In the presence of glucagon levels which enhanced glucose output and lactate uptake only submaximally, nerve stimulation altered the glucose and lactate balance to a similar extent as in controls [87]. Insulin, which under euglycemic conditions had no effect by itself, clearly reduced the nerve stimulation-dependent increase in glucose output without modifying the switch of lactate uptake to release [87,88]. Noradrenaline, adrenaline [89], vasopressin and angiotensin (Miura, H., Gardemann, A. , Rosa J. \& Jungermann, K., unpublished results), which themselves caused about half-maximal alterations, inhibited the nerve stimulation-induced increase in glucose and lactate output with descending effectivity. Since these substances did not influence noradrenaline overflow, the inhibitory effects were apparently caused by a postsynaptic and not by a presynaptic mechanism. 
Hemodynamic effects of sympathetic nerves

In portal-vein-perfused livers, nerve stimulation reduced portal flow [73]. In hepatic-artery-plus-portal-vein-perfused livers, stimulation of the arterial plexus caused a drastic decrease in arterial flow and also in portal flow; conversely, stimulation of the portal plexus led to a less pronounced decrease in portal flow and again a decrease in arterial flow (Fig. 3) [74]. The sum of the hemodynamic effects of single separate stimulations was greater than the effects of simultaneous separate or joint stimulation. Complex hemodynamic interactions between the hepatic artery and portal vein have also been observed in vivo [54,90].

Sympathetic-nerve stimulation not only altered perfusion flow, but also the intrahepatic distribution of the perfusate; infusion of trypan blue $20 \mathrm{~s}$ after onset of nerve stimulation resulted in a heterogeneous staining of the liver both at the surface and in cross-sections, while it led to a homogeneous distribution in non-stimulated controls $[82,84]$. A redistribution of perfusion flow upon nerve stimulation was also detected in vivo in rats using X-ray angiography [91] and in dogs using heat-conduction measurements [92]; it was, however, not observed in a study using radiolabelled microspheres [53].

A deeper insight into the function of the microcirculatory changes was provided by the observation in the perfused rat liver that, in periportal areas at the liver surface, the oxygen tension decreased immediately after stimulation of the arterial and portal plexuses, while, in contrast, in the perivenous zone it first increased sharply, then fell to low values [82--84]. The transient rise in the perivenous $\mathrm{pO}_{2}$ was probably caused by oxygen-rich perfusate, which was squeezed out by the blood reservoirs of the liver from the periportal zone through the perivenous zone. A nerve-stimulation-dependent constriction of the sinusoids had been observed before in morphological studies with rat liver in vivo [93].

The hemodynamic changes occurred within the physiological frequency range up to $20 \mathrm{~Hz}$ [29] with half-maximal effects around $1.5 \mathrm{~Hz}$ in portal-vein-perfused rat liver [86] and around $6 \mathrm{~Hz}$ in hepatic-artery-plus-portal-vein-perfused [74] rat liver. The latter value is similar to or higher than the corresponding values for glucose release. Thus, in the hepaticartery-plus-portal-vein-perfused and portal-vein-perfused liver, hepatic flow was less sensitive to hepatic nerve stimulation than glucose output. These results are in line with earlier studies in vivo [41, 43, 45, 53, 94]. Since hepatic flow changes, accompanied by an intrahepatic redistribution of flow, can be regarded to mirror the blood-reservuir function of the liver [86], these findings apparently show that acting as a blood reservoir is a liver function of lower priority than acting as a glucose store.

\section{Metabolic effects of parasympathetic nerves}

In portal-vein-perfused rat liver, parasympathetic stimulation (perivascular stimulation in the presence of the $\alpha$ blocker phentolamine and the $\beta$-blocker propranolol) had no influence on basal glucose metabolism either under euglycemic or under hyperglycemic conditions [95]. However, in the presence of insulin which under hyperglycemic conditions caused a small enhancement of glucose utilization, parasympathetic stimulation led to a further increase in glucose uptake. In the presence of glucagon, which also stimulated glucose release under hyperglycemic conditions, parasympathetic stimulation antagonized the glucagon-mediated glucose output. This

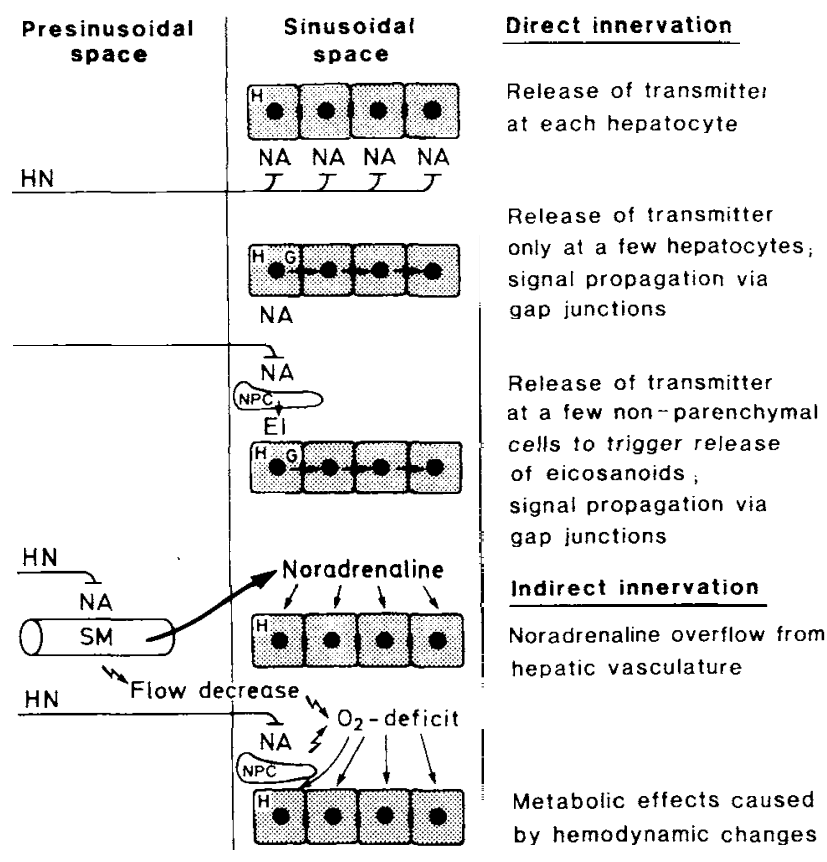

Fig. 5. Possible extrahepatocellular mechanisms of the action of sympathetic hepatic nerves on metabolism. HN, hepatic nerve; NA, noradrenaline; SM, smooth muscle; $\mathrm{H}$, hepatocyte; $\mathrm{G}$, gap junction; NPC, non-parenchymal liver cell; EI, eicosanoids.

nerve effect could be mimicked by acetylcholine and was prevented by the parasympathetic antagonist atropine. Also, insulin could antagonize the glucagon-stimulated glucose release; parasympathetic-nerve stimulation in the presence of insulin was even more effective than either stimulus alone [95].

\section{Hemodynamic effects of parasympathetic nerves}

In the liver perfused via the portal vein, parasympathetic nerve stimulation did not alter the perfusion flow [95]. In invivo studies it was observed that vagal stimulation opened sinusoids which had previously been closed [58, 59]. It was speculated that parasympathetic nerves may not change the overall liver flow, but cause an extensive redistribution of hepatic blood [54].

\section{MECHANISM OF ACTION OF SYMPATHETIC HEPATIC NERVES}

Signal propagation from the nerve cells to the effector cells

\section{Noradrenaline release}

The primary event following electrical stimulation of the hepatic sympathetic nerves is the release of noradrenaline from the varicosities at the nerve terminals. Noradrenaline is eliminated from its site of action by re-uptake into the nerve endings, degradation by the liver cells and diffusion into the vascular bed. The difference between noradrenaline release reuptake plus degradation can be measured as noradrenaline overflow into the hepatic vein, which reaches a maximum about $0.5-1.5 \mathrm{~min}$ after the onset of stimulation $[74,86]$ (Fig. 3). The release of noradrenaline from the nerve endings and thus the noradrenaline overflow and all effects of electrical-nerve stimulation are strictly dependent on the presence of extracellular calcium $[73,96,97]$. 
Table 3. Nerve effects remaining in perfused rat liver in the presence of gap junction inhibitors or after partial hepatectomy. pph, post two thirds partial hepatectomy. The values in control experiments were set equal to $100 \%$. Values are means \pm SEM of $3-5$ experiments. Significance in Student's $t$-test for unpaired values. Data are from [103, 104]. pmA, 4 $\beta$-phorbol 12-myristate 13-acetate.

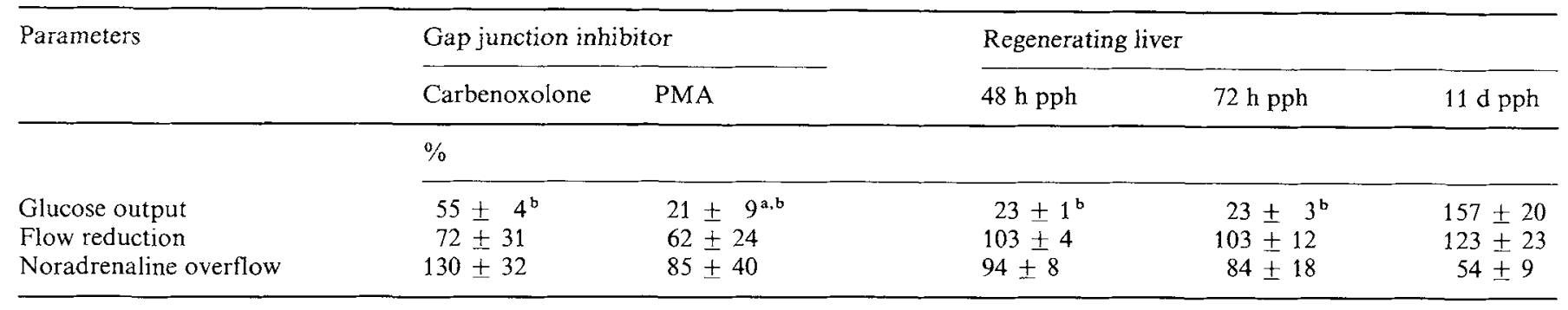

In control experiments the noradrenaline-dependent glucose output was lowered to $70 \%$.

${ }^{b} P<0.01$.

\section{Metabolism}

Noradrenaline action. The metabolic effects of sympathetic hepatic nerve stimulation are mediated via $\alpha$ receptors. The increase in glucose, lactate and uric acid output can be inhibited by the $\alpha$-receptor blockers phentolamine or prazosin almost completely both in monovascular and bivascular perfusions [73-76]. A study of monovascular perfusion using the subtype-specific $\alpha_{1}$-receptor, $\alpha_{2}$-receptor, $\beta_{1}$-receptor and $\beta_{2}$-receptor blockers prazosin, yohimbine, metoprolol and butoxamine provided evidence only for the involvement of $\alpha_{1}$ adrenergic receptors in the signal chain of events, whereas $\alpha_{2}$, $\beta_{1}$ and $\beta_{2}$ receptors seemed to play no role [75]. Yet, in liver perfused simultaneously via the hepatic artery and the portal vein, propranolol attenuated the nerve stimulation-dependent increase in glucose and lactate output, indicating that $\beta$ receptors, which were accessible only in the bivascular perfusion, had a permissive role in the regulation of carbohydrate metabolism by the sympathetic hepatic nerves [74]. This permissive action could not be attributed to a modulation by presynaptic $\beta$ receptors of noradrenaline and cotransmitter release from the nerve endings [75].

Direct regulation of liver metabolism by hepatic nerves. The metabolic effects of hepatic sympathetic nerves could be mediated either directly by contact of the nerve endings with the hepatocytes or indirectly by the overflow of noradrenaline from the vasculature or by a hypoxia due to the flow reduction (Fig. 5). These two indirect mechanisms could be excluded. Noradrenaline not taken up into the nerve endings at the smooth muscles of the vasculature and carried to the hepatocytes with the blood stream, should not reach the hepatocytes in perfusions with retrograde direction from the hepatic vein to the portal vein. Yet, metabolic alterations after nerve stimulation in retrograde perfusions were almost equal to those in orthograde perfusions [97]. In addition, circulating noradrenaline had no effect on glucose or lactate output in concentrations that could be expected to result from release of noradrenaline from the nerve endings into the circulation. The hypothesis that the metabolic effects of nerve stimulation were a mere consequence of an impaired sinusoidal circulation resulting in hepatocellular hypoxia could be dismissed, since the nerve-stimulation-elicited increase in glucose and lactate output remained nearly unaffected when the flow reduction was prevented by sodium nitroprusside [73, 97] or nifedipine [98]. Similarly, the nerve-stimulation-dependent formation of ketone bodies [78, 88], allantoin and uric acid [76], conjugation of xenobiotics [80] and secretion of bile [81] were independent of flow changes in contrast to the changes in urea, glutamine and ammonia balance [79] (not shown). Thus, hepatic sympathetic nerves seemed to regulate the metabolism of carbohydrates and ketone bodies or the conjugation of xenobiotics directly and the metabolism of nitrogenous compounds indirectly.

Involvement of gap junctions. The question was addressed as to whether every single hepatocyte is reached by the nerve endings or only some periportally located cells. In the latter case, the signal could be further propagated via gap junctions between hepatocytes. Large interspecies differences were found both on the basis of anatomical $[15,18,19]$ and biochemical studies [99]. Thus, the liver parenchyma of guinea pig and tree shrew is densely innervated and has few gap junctions, whereas the parenchyma of the rat is scarcely innervated at the periportal borders of the acinus, but is rich in gap junctions [19]. Electrical stimulation of the hepatic nerves in these three species elicited about equal increases in glucose output, however, in guinea pig and three shrew livers, the noradrenaline content and its overflow were $6-7$-fold higher than in rat liver, in line with the denser innervation [99]. Thus, signal propagation via gap junctions might be of outstanding importance in rat liver. This was demonstrated by two approaches. (1) Rat liver regenerating after partial hepatectomy was found to contain a clearly reduced number of gap junctions $[100,101]$. After $67 \%$ partial hepatectomy, the liver remnant reached $59 \%$ of the original liver mass after $48 \mathrm{~h}$, and $75 \%$ of the original liver mass after $72 \mathrm{~h}$ [102], whereas gap junctions had not been redeveloped $[100,101]$. Stimulation of hepatic nerves in perfused rat liver resulted in a flow reduction and a noradrenaline overflow similar to that observed in control livers, indicating that the nerves were functioning [103] (Table 3). Nevertheless, the stimulation-dependent increase in glucose output was reduced by $80 \%$. Eleven days after partial hepatectomy, the gap junctions were re-expressed and the nerve-stimulation-mediated increase in glucose output reached control levels again. (2) Gap junctions were inhibited by the glycerrhetinic acid derivative carbenoxolone or low concentrations of the phorbol ester $4 \beta$ phorbol 12-myristate 13-acetate. Again, the nerve-stimulation-dependent increase in glucose output was inhibited by $50 \%$ and $80 \%$, respectively [104], whereas noradrenaline overflow was not significantly affected (Table 3 ). Both studies together provide strong evidence that about $50 \%$ of the metabolic nerve effects in rat liver are mediated via signal propagation through gap junctions (see below and Fig. 8).

Involvement of eicosanoids. Nerve endings are not only in contact with the parenchymal liver cells (hepatocytes), but also with non-parenchymal liver cells, especially 

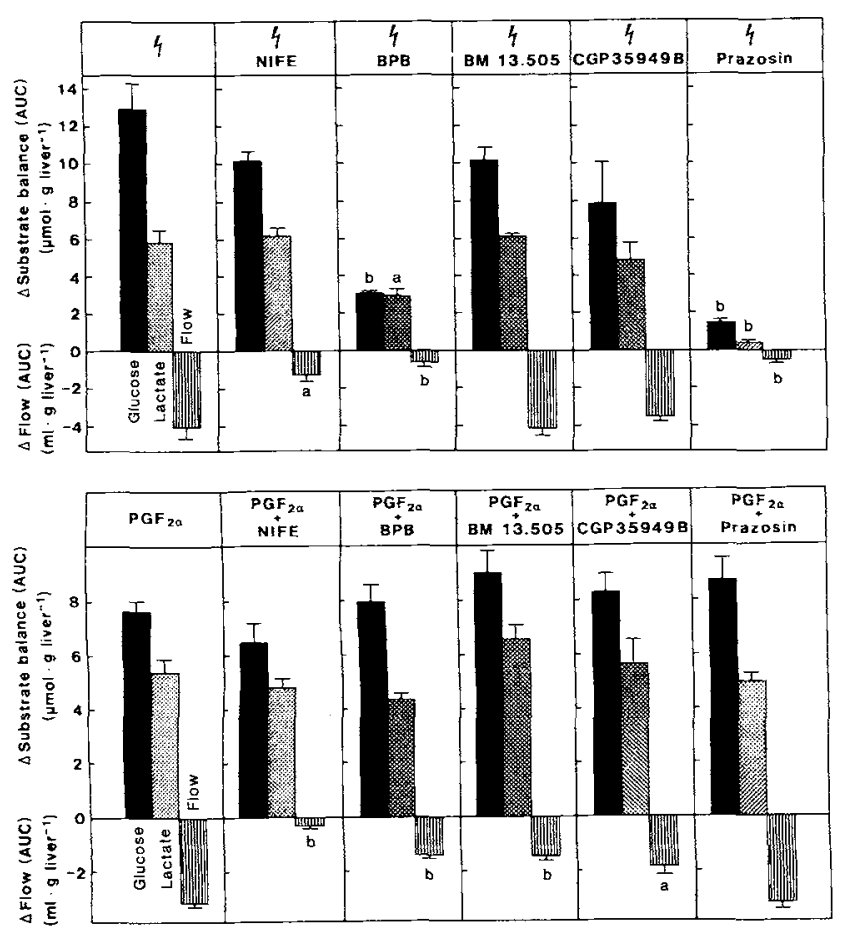

Fig. 6. Inhibition by the $\alpha_{1}$-receptor blocker prazosin, the calcium-channel blocker nifedipine and eicosanoid synthesis and receptor blockers of nerve-stimulation-dependent or prostaglandin $F_{2 \alpha}$-dependent alterations in glucose and lactate balance and perfusion flow in perfused rat liver. Rat livers were perfused via the portal vein with a Krebs-Henseleit buffer containing $5 \mathrm{mM}$ glucose, $2 \mathrm{mM}$ lactate and $0.2 \mathrm{mM}$ pyruvate. Perivascular nerves were stimulated $(20 \mathrm{~Hz}, 2 \mathrm{~ms}, 20 \mathrm{~V})$ or prostaglandin $F_{2 x}\left(\mathrm{PGF}_{2 x}, 10 \mu \mathrm{M}\right)$ was infused for $5 \mathrm{~min}$. Where indicated, the following inhibitors were infused before and during the stimulation: Nifedipine (NIFE, $25 \mu \mathrm{M}$ ), bromophenacylbromide (BPB, $20 \mu \mathrm{M}$ ) the thromboxane receptor antagonist BM $13505(20 \mu \mathrm{M})$ the leukotriene receptor antagonist CGP $35949 \mathrm{~B}(20 \mu \mathrm{M})$ and the $\alpha_{1}$ receptor antagonist prazosin $(10 \mathrm{nM})$. Alteration are shown as areas under the curves. Value are means \pm SEM of three experiments each. Statistics: Student's $t$-test for unpaired values, ${ }^{a} P<0.01,{ }^{b} P<$ 0.005. Data are from $[117,118,121]$, Iwai, M. \& Jungermann, K. (unpublished results).

perisinusoidal cells (Ito or fat-storing cells) [10]. Only nonparenchymal liver cells can form eicosanoids (prostaglandins, thromboxanes and leukotrienes) from arachidonate, which is released from phospholipids by the action of phospholipase $\mathrm{A}_{2}$ and converted to prostaglandins and thromboxanes via the cyclooxygenase pathway and to leukotrienes via the $5^{\prime}$ lipoxygenase pathway [105]. Prostanoid production and release is elicited in non-parenchymal liver cells by a variety of physiological, pathophysiological and chemical stimuli, which also increase glucose and lactate output and vascular resistance in perfused rat liver. Among these stimuli are extracellular nucleotides [106], nucleosides [107], zymosan [108, 109], endotoxin [110], aggregated immunoglobulins [111], anaphylatoxins [112, 113], phorbol esters [114] and calcium ionophores [106]. This led to the hypothesis, that eicosanoids might also play a role in the signal chain after nerve stimulation. Noradrenaline and/or other cotransmitters released from the nerve endings could stimulate prostanoid formation in nearby non-parenchymal liver cells. Prostanoids, in turn, might modulate metabolism in parenchymal cells (Fig. 5).

Indeed, the nerve-stimulation-dependent metabolic alterations could be inhibited in rat [115] and guinea pig [99] livers

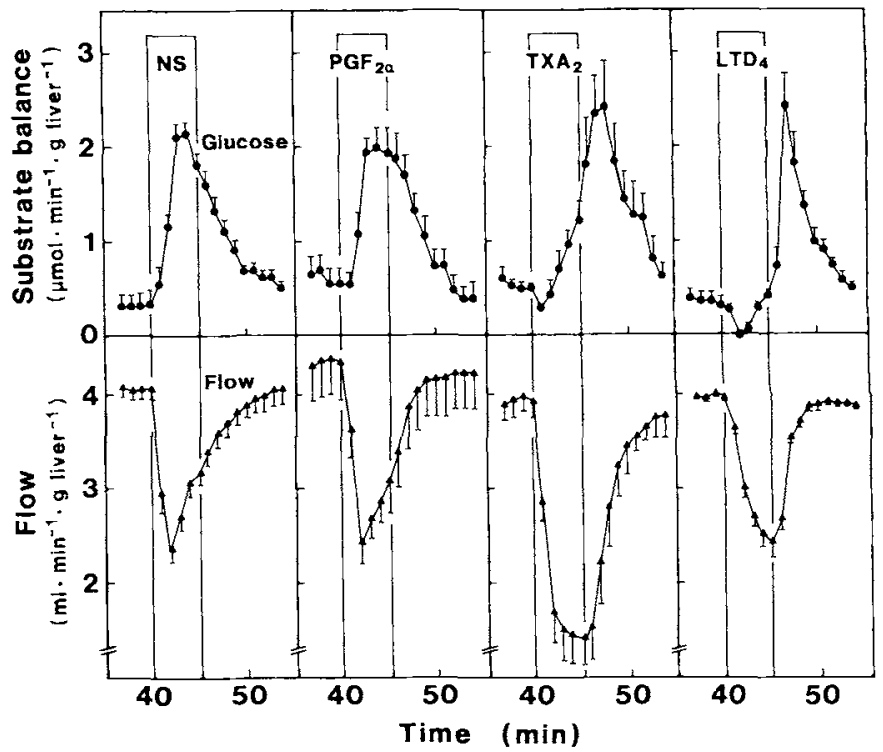

Fig. 7. Alteration by perivascular nerve stimulation, prostaglandin $\mathbf{F}_{2 \alpha}$, the thromboxane analog $U \mathbf{4 6 6 1 9}$ or leucotriene $D_{4}$ of glucose output and flow in perfused rat liver. Livers were perfused via the portal vein with constant pressure with Krebs-Henseleit buffer containing $5 \mathrm{mM}$ glucose, $2 \mathrm{mM}$ lactate and $0.2 \mathrm{mM}$ pyruvate. Where indicated, either perivascular nerves were stimulated ( $\mathrm{NS} 20 \mathrm{~Hz}, 2 \mathrm{~ms}, 20 \mathrm{~V}$ ), or prostaglandin $F_{2 \alpha}$ (prostaglandin $\left.F_{2 \alpha}, 10 \mu \mathrm{M}\right), U 46619\left(\mathrm{TXA}_{2}, 100 \mathrm{nM}\right)$ or leucotriene $\mathrm{D}_{4}\left(\mathrm{LTD}_{4}, 20 \mathrm{nM}\right)$ were infused. Values are means \pm SEM of nine (NS) or three $\left(\mathrm{PGF}_{2 \alpha}, \mathrm{TXA}_{2}, \mathrm{LTD}_{4}\right)$ experiments. Data are from $[117,118]$.

by the phospholipase $A_{2}$ inhibitor bromophenacylbromide, which also inhibits prostaglandin $D_{2}$ synthesis [116], and by the cyclooxygenase inhibitor indomethacin without affecting the noradrenaline overflow (Fig. 6). In contrast, neither the 5 -lipoxygenase inhibitor nordihydroguaiaretic acid nor the leukotriene receptor antagonist $N-\{3-[3-(4-a c e t y\}-3-h y d r o x y-$ 2 - propylphenoxy)propoxy] - 4-chlorine - 6 - methyl - phenyl\}1H-tetrazole-5-carboxamide (CGP 35949 B) or the thromboxane receptor antagonist 4-[2-(4-chlorobenzene sulfonamide)ethyl]benzeneacetic acid (BM 13505) diminished the nerve effects [115] (Fig. 6). Prostaglandins $F_{2 \alpha}, D_{2}$ and $E_{2}$, as well as the thromboxane $\mathrm{A}_{2}$ analog U46619 $\left(\mathrm{TXA}_{2}\right)$ and leukotrienes $\mathrm{C}_{4}$ and $\mathrm{D}_{4}$, the latter with a delay, increased glucose and lactate output in perfused liver [117-120]. However, only the prostaglandins, especially prostaglandin $F_{2 \alpha}$, mimicked the effects elicited by the hepatic nerves in showing an 'escape phenomenon' (Fig. 7), that is metabolite output started to return to values observed before stimulation, despite continued stimulation [117]. The delay in the metabolic actions of TXA $\mathrm{A}_{2}$, leukotrienes $\mathrm{C}_{4}$ and $\mathrm{D}_{4}$ was the result of two opposing effects; the perfused parenchyma and thus metabolite output was reduced. This reduction was later compensated for by an increase in metabolism in the parenchymal cells which were still perfused. After cessation of the TXA $\mathrm{A}_{2}$, leukotriene $\mathrm{C}_{4}$ or leukotriene $\mathrm{D}_{4}$ application, previously unperfused areas of the liver where reperfused and glucose and lactate, accumulated in the sinusoids, were washed out.

These observations, together with the data obtained in the inhibitor studies, suggested that prostaglandins, but not thromboxanes or leukotrienes, played a role in the signal chain of events after nerve stimulation. This view gains further support from the comparison of different inhibitors on the action of nerve stimulation and prostaglandin $\mathrm{F}_{2 \alpha}$ (Fig. 6). As 
with nerve stimulation, nordihydroguaiaretic acid, leukotriene and thromboxane receptor antagonists did not attenuate the prostaglandin $\mathrm{F}_{2 \alpha}$-elicited increase in metabolite output, nor did prazosin, bromophenacylbromide or nifedipine (see below).

The participation of prostaglandins in a signal chain of events from the nerve cell to the hepatocyte depends upon the existence of hepatocellular prostaglandin receptors. Evidence for the existence of such a receptor has accumulated. Prostaglandin $\mathrm{F}_{2 \alpha}[121], \mathrm{E}_{2}[122]$ and $\mathrm{D}_{2}$ [123] stimulated glycogen phosphorylase activity or glucose release in hepatocyte suspensions, whereas the $\mathrm{TXA}_{2}$ was inactive [121]. As in liver perfusions, half-maximal stimulation of glycogenolysis was observed in the concentration range $0.5-5 \mu \mathrm{M}$ for all three prostaglandins (Püschel, G. P., Schröder, A. and Jungermann, $\mathrm{K}$., unpublished results). The prostaglandins increased inositol 1,4,5-trisphosphate but not cAMP [121, 122]. A common low affinity binding site with a $K_{d}$ of about $2 \mu \mathrm{M}$ could be demonstrated in hepatocyte plasma membranes besides a prostaglandin $\mathrm{F}_{2 \alpha}$-specific high-affinity binding site, for which a biological function is currently not evident (NeuschäferRube, F., Püschel, G. P. and Jungermann, K., unpublished results). In other studies with hepatocyte suspensions, prostaglandin $\mathrm{D}_{2}$ stimulated glycogenolysis half-maximally at concentrations of $20 \mathrm{nM}$ and a prostaglandin $\mathrm{D}_{2}$-specific binding site with a $K_{\mathrm{d}}$ in the same concentration range was described [123].

\section{Hemodynamics}

Noradrenaline action. The nerve-stimulation-mediated flow reduction was inhibited almost completely by the $\alpha$ receptor antagonist phentolamine [73], and the $\alpha_{1}$-receptorspecific antagonist prazosin (Fig. 6) [74], but not by $\alpha_{2}$-receptor, $\beta_{1}$-receptor and $\beta_{2}$-receptor blockers [75] and hence was mediated via $\alpha_{1}$ receptors. This could point to a direct contact of the nerve endings with the vascular smooth muscle cells regulating the flow.

Involvement of eicosanoids. Flow reduction was also inhibited by the phospholipase $\mathrm{A}_{2}$ /prostaglandin $\mathrm{D}_{2}$-synthesisinhibitor bromophenacylbromide (Fig. 6) and by the cyclooxygenase inhibitor indomethacine [99, 115]. Thus, the possibility can be envisaged that the nervous regulation of liver hemodynamics was at least partly mediated via stimulation of eicosanoid formation in non-parenchymal liver cells. As with the metabolic effects of nerve stimulation, neither nordihydroguaiaretic acid nor leukotriene or thromboxane receptor antagonists [118] interfered with flow reduction to a significant extent (Fig. 6), indicating that only prostaglandins, but not thromboxanes or leukotrienes, participated in flow regulation by the sympathetic hepatic nerves. Prostaglandins, especially prostaglandin $F_{2 \alpha}$, mimicked the nerve-stimulationmediated flow reduction in kinetics and extent [117]. Bromophenacylbromide and, in contrast to nerve stimulation, also thromboxane-receptor and leukotriene-receptor antagonists (Iwai, M. and Jungermann, K., unpublished results), attenuated the prostaglandin $\mathrm{F}_{2 \alpha}$-elicited flow reduction slightly but significantly (Fig. 6). This might indicate that the flow effects of circulating prostaglandin $\mathrm{F}_{2 a}$, in contrast to those of prostaglandin $F_{2 \alpha}$ released locally after nerve stimulation, could in part act via stimulation of leukotriene and thromboxane production in other non-parenchymal liver cells. Prazosin did not alter the prostaglandin $\mathrm{F}_{2 \alpha}$-mediated flow reduction, but the calcium channel blocker nifedipine abolished it $[98,118]$ (see below).

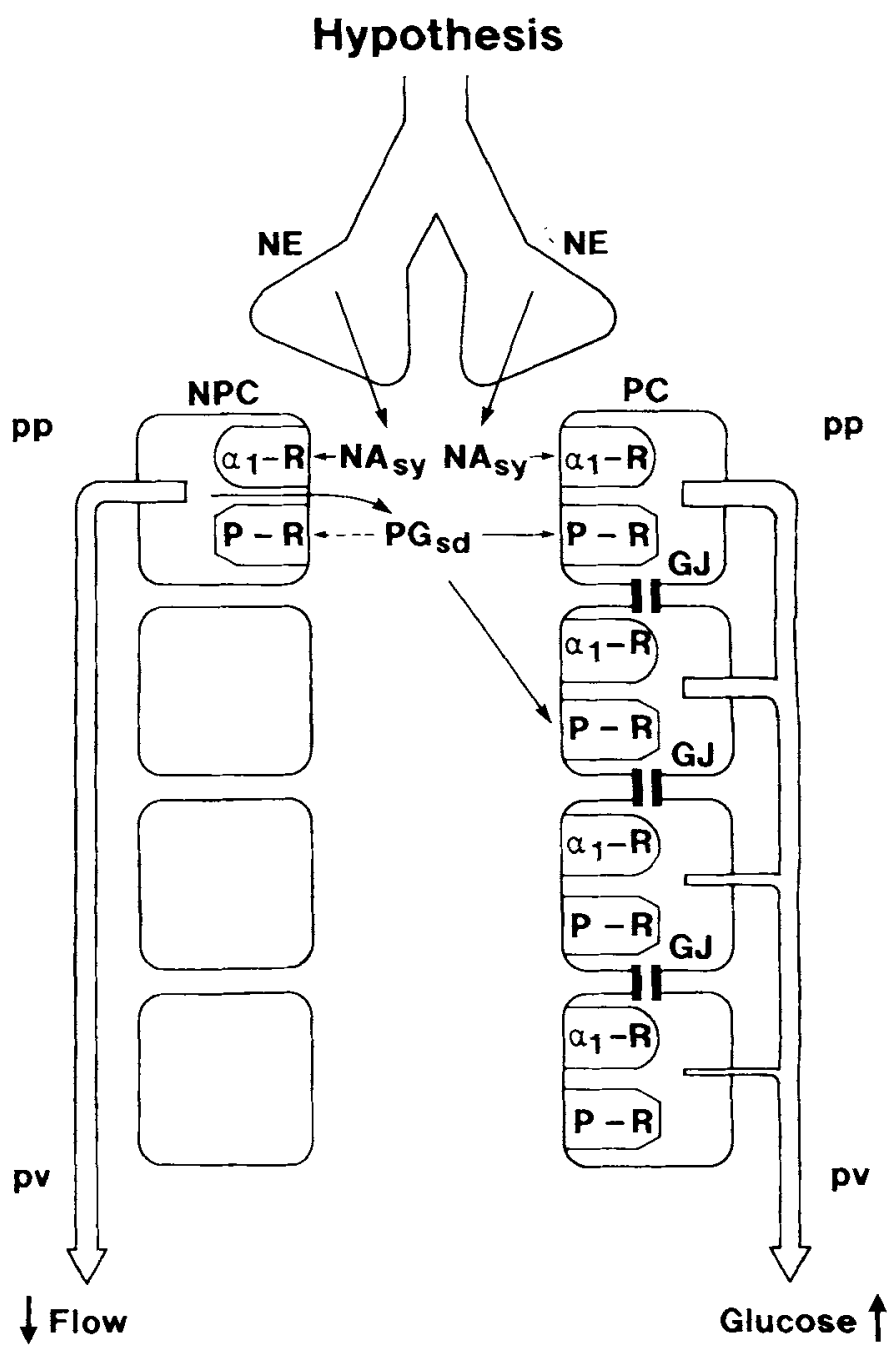

Fig. 8. Model for the signal propagation from nerve endings to the effector cells in rat liver. NE, nerve ending; NPC, non-parenchymal cell; PC, parenchymal cell; $\mathrm{NA}_{\text {sy }}$, synaptically released noradrenaline; $\mathrm{PG}_{\mathrm{sd}}$, prostaglandins, locally released into the space of Disse; $\alpha_{1}$ $\mathrm{R}, \alpha_{1}$-receptor; P-R, prostaglandin receptor; GJ, gap junction; pp, periportal zone; $\mathrm{pv}$, perivenous zone. The model is explained in the text.

\section{Hypothetical signal chain from nerve endings to the effector cells}

The model. Since the metabolic and hemodynamic effects of hepatic nerve stimulation were inhibited by the $\alpha_{1}$-receptor blocker prazosin and by bromophenacylbromide or indomethacin, and since the actions of prostaglandin $F_{2 \alpha}$ are unaffected by prazosin, noradrenaline and the $\alpha_{1}$ receptor must preceed prostaglandin and the prostaglandin receptor in the signal chain. Noradrenaline released from periportally located nerve endings might act partly via $\alpha_{1}$ receptors on nearby hepatocytes or partly via $\alpha_{1}$ receptors on nonparenchymal liver cells, which in turn can release prostaglandins. Noradrenaline and prostaglandins would then stimulate glycogenolysis in neighbouring hepatocytes. The signal might be further propagated to more distant hepatocytes via gap junctions (Fig. 8), which have been shown to be permeable to inositol 1,4,5-trisphosphate and $\mathrm{Ca}^{2+}$. In freshly isolated pairs or clusters of hepatocytes, signal propagation was mediated by the transjunctional flux of these intracellular messengers [124]. Similarly, noradrenaline released from nerve endings 
might act partly via $\alpha_{1}$ receptors on smooth muscle cells of the hepatic blood vessels and partly via $\alpha_{1}$ receptors on nonparenchymal liver cells, which in turn could release prostaglandins. Again, noradrenaline and prostaglandin would then cause a constriction of the sinusoids (Fig. 8).

Caveats to the model. The studies with inhibitors of eicosanoid synthesis do not prove the model, since inhibition might be caused by yet unknown unspecific side effects of these drugs. The model could be further supported by a prostanoid overflow into the hepatic vein, as has been shown after infusion of nucleotides, nucleosides, zymosan, endotoxin, aggregated immunoglobulins, anaphylatoxins, phorbol esters and calcium ionophores (see above) that stimulate glucose output and reduce flow in perfused livers. Such an overflow has not yet been demonstrated in a convincing manner after nerve stimulation. The overflow of prostaglandin $\mathrm{D}_{2}$ and prostaglandin $E_{2}[106]$ was at the edge of significance and with concentrations of $2.5 \mathrm{nM}$ and $0.1 \mathrm{nM}$ far below the range in which physiological responses to prostaglandins have been observed. One has, however, to keep in mind that the overflow is only the difference between prostaglandin formation and degradation during the passage through the sinusoids. In fact, prostaglandins are very efficiently degraded by the liver. Thus, $90-95 \%$ of prostaglandin $\mathrm{E}_{2}$ was extracted during a single passage through the sinusoids in rat liver perfused with defibrinated blood [125] and more than $95 \%$ of prostaglandin $\mathrm{F}_{2 \alpha}$ immunoreactivity was eliminated during one passage through livers perfused with a Krebs-Henseleit buffer (Püschel, G. P., Hülsmann, M. and Jungermann, K., unpublished results). Taking into account that nerve action, in contrast to the circulating agents mentioned above, probably stimulates only a few periportally located non-parenchymal liver cells to release prostaglandins, a small or even lacking prostaglandin overflow does not argue against the participation of prostaglandins in the signal chain of events. In order to be a link in the signal chain of events from the nerve to the effector cell, non-parenchymal liver cells should possess $\alpha$ receptors and should react to stimulation by $\alpha$ agonists with prostaglandin formation. This has not yet been shown. Studies tempting to elucidate this are under way.

\section{Signal chain within the effector cell}

\section{Metabolism}

Following stimulation of the hepatic nerves, the activity of glycogen phosphorylase increased, that of glycogen synthase decreased and that of glycolytic pyruvate kinase remained unaffected. The level of the activators of glycogenolysis (cAMP) and glycolysis (fructose-2,6-bisphosphate), increased slightly [96]. The slight increase in cAMP could not account for the increase in glycogen phosphorylase activity. Therefore, it was assumed that liver nerves enhanced hepatic glucose output via an increase in the cytosolic calcium concentration (Fig. 9). A transient release of $\mathrm{Ca}^{2+}$ into the perfusate, followed by a prolonged reuptake of $\mathrm{Ca}^{2+}$ after nerve stimulation favoured this view [77]. There was no evidence for entry of extracellular calcium via nifedipine-sensitive calcium channels [98].

The possible involvement of intracellular calcium in the 'metabolic' signal chain of events was tested in 'calcium deprivation/replenishment' experiments [96]. The idea was that intracellular calcium pools should be emptied during a prolonged calcium-free perfusion and, thus, processes depending on intracellular calcium should be inhibited. After re-

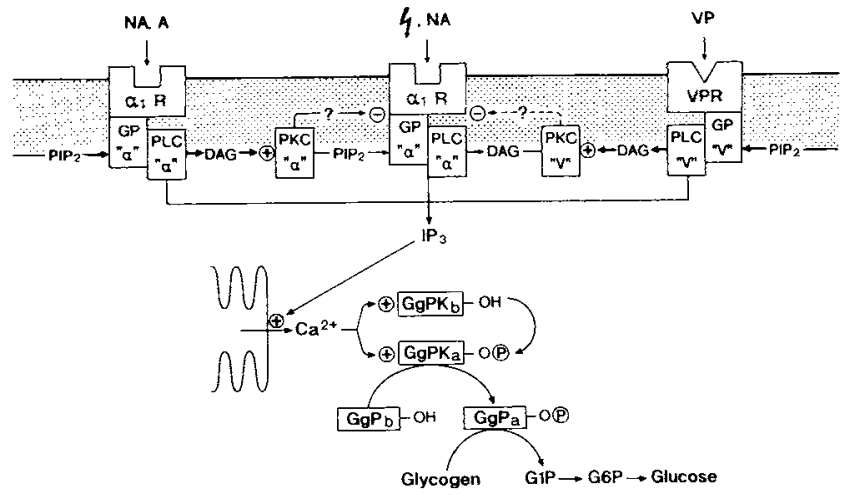

Fig. 9. Scheme of the mechanism of inhibition by noradrenaline, adrenaline and vasopressin of the nerve stimulation-dependent and noradrenaline-dependent alterations of metabolism and hemodynamics in rat liver. A, adrenaline; NA, noradrenaline; VP, vasopressin; $\alpha_{1} R$, $\alpha_{1}$ receptor; VPR, vasopressin receptor; GP , $\alpha^{\prime \prime}$, putative $\alpha_{1}$-receptorcoupled guanosine-nucleotide-binding regulatory protein; GP „V", putative vasopressin-receptor-coupled guanosine-nucleotide-binding regulatory protein; PKC „, $\alpha^{*}, \mathrm{PKC}, \mathrm{V}^{*}$ and PLC $, \alpha^{\prime}, \mathrm{PLC}, \mathrm{V}^{*}$, putative agonist-specific protein kinase $C$ and phospholipase $C ; \mathrm{PIP}_{2}$ phosphatidylinositol 4,5-bisphosphate; DAG, 1,2-diacylglycerol; $\mathrm{IP}_{3}$, inositol 1,4,5-trisphosphate; G1P (G6P), glucose 1(6)-phosphate; $\mathrm{GgP}(\mathrm{K})$ glycogen phosphorylase (kinase).

addition of calcium to the extracellular medium, processes depending on intracellular calcium should still be inhibited or at least delayed, since replenishment of intracellular calcium pools is a relatively slow process, lasting $2-3 \mathrm{~min}$. Processes depending on extracellular calcium, however, should be possible immediately after adding calcium to the medium. In calcium-free perfusions, nerve-stimulation-dependent metabolic alterations occurred with normal kinetics when calcium was added $3 \mathrm{~min}$ prior to stimulation; they were, however, delayed when calcium was added only 2 min after the onset of stimulation. This indicated that calcium release from intracellular pools was involved in the signal chain [96] (Fig. 9).

The second messenger causing a release of calcium from intracellular pools is generally thought to be inositol 1,4,5trisphosphate, which, together with diacylglycerol, is released from phosphatidyl inositol 4,5-bisphosphate after stimulation of $\alpha_{1}$ receptors. Both noradrenaline [126, 127] and prostaglandins $[121,122]$ have been shown to increase inositol 1,4,5trisphosphate in hepatocytes. In perfused livers, however, a significant increase in inositol 1,4,5-trisphosphate could not be demonstrated after nerve stimulation, but only after infusion of noradrenaline [128]. This result would fit the hypothesis that, during nerve action, only a few periportal hepatocytes are directly stimulated by noradrenaline or prostaglandins, leading to a small local increase in inositol $1,4,5$ trisphosphate which is not measurable in whole liver homogenates, and that the signal is then propagated to the majority of hepatocytes via gap junctions (Fig. 8).

The metabolic nerve actions were inhibited by so-called calcium-releasing hormones such as adrenaline, noradrenaline [89], vasopressin and angiotensin (Miura, H., Gardemann, A., Rosa, J. and Jungermann, K., unpublished results) (Fig. 9), which increase inositol 1,4,5-trisphosphate and diacylglycerol, and by high concentrations of the phorbol ester $4 \beta$-phorbol 12-myristate 13 -acetate. Diacylglycerol and $4 \beta$-phorbol 12 myristate 13-acetate would activate protein kinase $C$, which is known to inhibit the $\alpha_{1}$-receptor-mediated hydrolysis of phosphatidyl inositol 4,5-bisphosphate to inositol 1,4,5- 


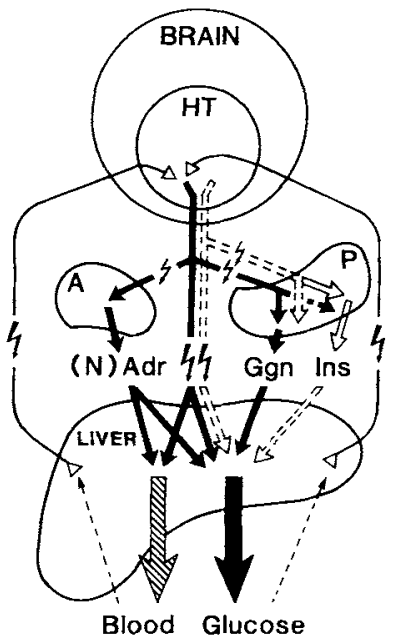

Fig. 10. The nervous humoral network for the maintenance of the hepatic glucostat and blood reservoir function. A, adrenals; P, pancreas; HT, hypothalamus; (N)Adr, (nor)adrenaline; Ggn, glucagon; Ins, insulin; $N$, nervous activity. The sympathetic, adrenergic and glucagon system are shown with filled arrows, the parasympathetic and insulin system with open arrows. Uninterrupted lines, activation; broken lines, inhibition.

trisphosphate [129]. These findings would corroborate the participation of inositol 1,4,5-trisphosphate in the nerve-signal chain of reactions.

Hemodynamics. The hemodynamic nerve effects were inhibited by the calcium-channel blocker nifedipine (Fig. 6) [98]. In the 'calcium deprivation/replenishment' experiments, the nerve-stimulation-mediated flow reduction was restored immediately after readdition of calcium [96]. Thus, the hemodynamic nerve effects were dependent on the entry of extracellular calcium into the smooth muscle cells. Within the cell, $\mathrm{Ca}^{2+}$ would activate the calmodulin-dependent myosin light chain kinase and thus cause constriction. The attenuation of the flow effects by sodium nitroprusside [73], which decreases the sensitivity of the system to calmodulin by increasing cGMP, would also be in line with this mechanism.

\section{Functions of sympathetic}

\section{and parasympathetic nerve actions}

The liver is both the central organ for the maintenance of the energy supply, mainly by operating as a glucostat and also an active and passive blood reservoir [6, 7] (Table 1). A network of afferent and efferent, sympathetic and parasympathetic nerves is important for the regulation of the glucose and blood reservoir function of the liver. The network senses the blood glucose concentration and blood pressure $[25,26,66-72]$ and influences hepatic metabolism and hemodynamics directly via liver nerves and indirectly via modifying the hormonal secretion rates of other organs, such as the pancreas and adrenal medulla (Fig. 10).

Activation of the sympathetic nervous system signals that the organism requires glucose and blood. The total amount of glucose and part of the required blood are provided by the liver in which some tissue areas release blood to the circulation by being squeezed out and temporarily restricted from receiving further blood supply and in which other tissue areas remain accessible mainly for the increased release of systemically required glucose. Major signals for an increase in glucose output are declining glucose levels, increased portovenous concentrations of glucagon, enhanced systemic levels of catecholamines and an increased tone of the sympathetic liver nerves. Major signals for release of blood are elevated concentrations of circulating catecholamines and again an increased tone of the sympathetic hepatic nerves. Thus, the sympathetic nervous system, activated in part via afferent hepatic nerve fibers [25, 26, 66-72], appears to control the glucose and the blood-reservoir functions mainly directly via sympathetic liver nerves and also indirectly by activating the release of glucagon from the pancreas and of adrenaline and noradrenaline from the adrenal medulla (Fig. 10).

After a normal meal, the liver takes up a substantial part of the absorbed glucose. Major signals for the activation of glucose uptake are an increased glucose concentration gradient between the portal vein and the hepatic artery [130], an increased portovenous level of insulin and an enhanced tone of the parasympathetic liver nerves. The parasympathetic nervous system enhances hepatic glucose uptake indirectly by stimulation of insulin release and reduction of the activity of the hepatic branch of efferent splanchnic nerve fibers [69] and of the level of circulating catecholamines as well as directly via the hepatic nerves antagonistically to glucagon and synergistically with insulin (Fig. 10) [95].

\section{REFERENCES}

1. Jungermann, K. \& Katz, N. (1989) Physiol. Rev. 69, 708-764.

2. Jungermann, K. (1988) Semin. Liver Dis. 8, 329-341.

3. Wisse, E., Geerts, B., Bouwens, L, Van Bossuyt, K., Vanderkerken, K. \& Van Goethem, V. (1989) in Cells of the hepatic sinusoid 1988, an attempt to review the 4th International Kupffer cell symposium in cells of the hepatic sinusoids (Wisse, E., Knook, D. L. \& Decker, K., eds), pp. 1-7, Kupffer Cell Foundation, Leiden, Netherlands.

4. Bouwens, L, De Bleser, P. Vanderkerken, K. Geerts, B. \& Wisse, E. (1992) Enzyme, in the press.

5. Sawchenko, P. E. \& Friedman, M. I. (1979) Am. J. Physiol. 236, R5 - R20.

6. Lautt, W. W. (1980) Can. J. Physiol. Pharmacol. 58, 105-123.

7. Lautt, W. W. (1983) Prog. Neurobiol. 21, 323-348.

8. Sutherland, S. D. (1965) Rev. Int. Hepatol. 15, 569-578.

9. Precht1, J. C. \& Powley, T. L. (1987) Anat. Embryol. 176, 115126.

10. Bioulac-Sage, P., Lafon, M. E., Saric, J. \& Balabaud, C. (1990) J. Hepatol. 10, $105-112$.

11. Friedman, M. I. ( 1988) in Hepatic nerve function in the liver (Arias, I. M., Jacoby, W. B., Popper, H., Schachter, D. \& Shafritz, D. A., eds) pp. 949-959, Raven Press Ltd., New York

12. Carobi, C., Della Torre, G. \& Magni, F. (1985) Neurosci. Lett. $62,255-260$.

13. Rogers, R. C., Kahrilas, P. J. \& Hermann, G. E. (1984) J. Auton. Nerv. Syst. 11, $223-225$.

14. Shimazu, T. (1981) Diabetologia 20, 343-356.

15. Forssmann, W. G. \& Ito, S. (1977) J. Cell. Biol. 74, $299-313$.

16. Tsuneki, K. \& Ichihara, K. (1981) Arch. Histol. JPN. 44, 1-13.

17. Moghimzadeh, E., Nobin, A.\& Rosengren, E. (1983) Cell Tissue Res. 230, 605-613.

18. Metz, W. \& Forssmann, W. G. (1980) in Communications of liver cells (Popper, H., Bianchi, L., Gudat, F. \& Reutter, W., eds) pp. 121-127, MTP Press, Lancaster.

19. Reilly, F. D., McCuskey, P. A. \& McCuskey, R. S. (1978) Anat. Rec. 191, 55-67.

20. Ungvary, G. \& Donáth, T. (1975) Exp. Mol. Pathol. 22, $29-$ 34.

21. Schubert, W., Metz, J. \& Forssmann, W. G. (1984) Verh. Anat. Ges. $78,461-462$. 
22. Forssmann, W. G. (1986) Z. Gastroenterol. Suppl. 21, $190-191$. 23. Burt, A. D., Tiniakos, D., MacSween, R. N., Griffiths, M. R., Wisse, E. \& Polak, J. M. (1989) Hepatology 9, 839-845.

24. Lundberg, I. M., Terenius, L. \& Hokfell, T. (1982) Acta Physiol. Scand. $116,477-480$

25. Ito, Y., Magari, S. \& Sakanaka, M. (1990) Arch. Histol. Cytol. 53 Suppl., 199-208.

26. Niijima, A. (1989) Prog. Neurobiol. 33, 135-147.

27. Niijima, A. (1989) J. Nutr. 119, 833-840.

28. Shimazu, T. (1983) Adv. Metab. Disord. 10, 355-384.

29. Niijima, A. (1979) in Integrative functions of the autonomic nervous system (Brooks, C. McC., Koizumi, K. \& Sato, A., eds), pp. 68-83, Elsevier, Amsterdam.

30. Cohen, M. I. \& Gootman, P. M. (1970) Am. J. Physiol. 218, $1092-1101$

31. Niijima, A. (1985) J. Physiol. 364, 105-112.

32. Niijima, A. (1991) Brain Res. Bull. 26, 165-167.

33. Shimazu, T. (1981) Diabetologia 20, 343-356.

34. Iwai, M. \& Shimazu, T. (1988) Life Sci. 42, 1833-1840.

35. Shimazu, T. \& Usami, M. (1982) J. Physiol. (Lond.) 329, 231 42.

36. Shimazu, T. \& Amakawa, A. (1968) Biochim. Biophys. Acta I65, $324-334$.

37. Shimazu, T.\& Amakawa, A. (1968) Biochim. Biophys. Acta I65, $335-348$

38. Proost, C., Carton, H. \& DeWulf, H. (1979) Biochem. Pharmacol. 28, 2187-2191.

39. Shimazu, T. \& Amakawa, A. (1968) Biochim. Biophys. Acta 165, $349-356$.

40. Edwards, A. V. (1971) J. Physiol. (Lond.) 213, 741-753.

41. Jarhult, J., Andersson, P. O., Holst, J., Moghimzadeh, E. \& Nobin, A. (1980) Acta Physiol. Scand. 110, 5-11.

42. Garceau, D., Yamaguchi, N., Goyer, R. \& Guitard, F. (1984) Can. J. Physiol. Pharmacol. 62, 1086-1091.

43. Edwards, A. V. (1972) J. Physiol. (Lond.) 220, 697-710

44. Edwards, A. V. \& Silver, M. (1972) J. Physiol. (Lond.) 223, $571-593$

45. Lautt, W. W. \& Wong, C. (1978) Can. J. Physiol. Pharmacol. $56,1022-1028$.

46. Nobin, A., Falck, B., Ingemanson, S., Järhuld, J. \& Rosengren, E. (1977) Acta Physiol. Scand. Suppl. 452, $103-106$.

47. Shimazu, T. \& Amakawa, A. (1975) Biochim. Biophys. Acta 385, $242-256$.

48. Lautt, W. W. (1977) Am. J. Physiol. 232, H652-H656.

49. Yoshimatsu, H., Niijima, A., Oomura, Y.\& Katafuchi, T. (1988) Brain Res. Bull. 21, 239-44.

50. Shimazu, T. \& Fujimoto, T. (1971) Biochim. Biophys. Acta 252, $18-27$.

51. Shimazu, T. (1971) Biochim. Biophys. Acta 252, 28-38.

52. Lautt, W. W. \& Wong, C. (1978) Can. J. Physiol. Pharmacol. $56,679-682$.

53. Greenway, C. V. \& Oshiro, G. (1972) J. Physiol. (Lond.) 227, 487-501.

54. Richardson, P. D. I. \& Withrington, P. G. (1982) Annu. Rev. Physiol. 44, 57-69.

55. Lautt, W. W. \& Legare, D. J. (1986) Can. J. Physiol. Pharmacol. $64,449-454$.

56. Lautt, W. W., Schafer, J. \& Legare, D. J. (1991) Can. J. Physiol. Pharmacol. 69, 43-48.

57. Friman, S., Radberg, G. \& Svanvik, J. (1990) Acta Physiol. Scand. 140, 287-293.

58. Koo, A. \& Liang, I. Y. S. (1979) Am. J. Physiol. 236, E728E732.

59. Koo, A. \& Liang, I. Y. S. (1979) J. Physiol. 295, 191-199.

60. Shanygina, K. I., Fomina, M. P., Parfenova, N. S. \& Kalashnikova, N. M. (1981) Vopr. Med. Khim. 27, 505-509.

61. Magni, F. \& Viola, M. P. (1985) J. Auton. Nerv. Syst. 13, 245254.

62. Ashirmetov, A. K. H. \& Krakovskii, M. E. (1990) Fiziol. Zh. (Kiev) 36, 43-46.

63. Albino Teixeira, A., Matias, A., da Silva, P. Soares, Sarmento, A. \& Azevedo, I. (1990) J. Auton. Pharmacol. 10, 181-189.
64. Lindfeldt, J., Holmin, T. \& Ahren, B. (1987) J. Auton. Nerv. Syst. 19, 211-217.

65. Hogestatt, E. D., Hammarstrom, L. E., Andersson, K. E. \& Holmin, T. (1986) Acta Physiol. Scand. 128, 309-315.

66. Niijima, A. (1982) J. Physiol. (Lond.) 332, 315-323.

67. Niijima, A. (1983) J. Auton. Nerv. Syst. 9, 207-220.

68. Nijima, A., Fukuda, A., Taguchi, T. \& Okuda, J. (1983) Am. J. Physiol. 244, R611-614.

69. Niijima, A. (1984) J. Auton. Nerv. Syst. 10, 279-285.

70. Donovan, C. M., Halter, J. B. \& Bergman, R. N. (1991) Diabetes $40,155-158$

71. Lee, K. C. \& Miller, R. E. (1985) Endocrinology 117, $307-314$.

72. Tanaka, K., Inoue, S., Nagase, H. \& Takamura, Y. (1990) Endocrinology 127, 2017-2023.

73. Hartmann, H., Beckh, K. \& Jungermann, K. (1982) Eur. J. Biochem. 123, $521-527$.

74. Gardemann, A., Strulik, H. \& Jungermann, K. (1987) Am. J. Physiol. 253, E238-E245.

75. Ulken, V., Püschel, G. P. \& Jungermann, K. (1991) Biol. Chem. Hoppe Seyler 372, $401-409$.

76. Püschel, G. P., Nath, A. \& Jungermann, K. (1987) FEBS Lett. $219,145-150$

77. Häussinger, D., Stehle, T., Gerok, W. \& Sies, H. (1987) Eur. J. Biochem. 163, 197-203.

78. Beuers, U., Beckh, K.\& Jungermann, K. (1986) Eur. J. Biochem. $158,19-24$.

79. Ballé, C. \& Jungermann, K. (1986) Eur. J. Biochem. 158, 1318.

80. Beuers, U., Pogonka, R., Esterline, R., Ji., S. \& Jungermann, K. (1986) Toxicol. Lett. 34, 247-252.

81. Beckh, K. \& Arnold, R. (1991) Am. J. Physiol. 261, G775G780.

82. Ji, S., Beckh, K. \& Jungermann, K. (1984) FEBS Lett. 167, $117-122$.

83. Beckh, K., Hartmann, H., Jungermann, K. \& Scholz, R. (1984) Pflügers Arch. 401, 104-106.

84. Beckh, K., Otto, R., Ji, S. \& Jungermann, K. (1985) Biol. Chem Hoppe Seyler 366, 671-678.

85. Seydoux, J., Brunsmann, M., Jeanrenaud, B. \& Girardier, L. (1979) Am. J. Physiol. 236, G323-G327.

86. Sannemann, J., Beckh, K. \& Jungermann, K. (1986) Biol. Chem. Hoppe Seyler 367, 401 - 409.

87. Beckh, K., Hartmann, H. \& Jungermann, K. (1982) FEBS Lett. $146,69-74$.

88. Küster, J., Beuers, U. \& Jungermann, K. (1989) Biol. Chem Hoppe Seyler 370, 1035-1044.

89. Miura, H., Gardemann, A., Rosa, J. \& Jungermann, K. (1992) Hepatology, in the press.

90. Withrington, P. G. \& Richardson, P. D. I. (1986) in Regulation of hepatic metabolism (Thurman, R. G., Kauffman, F. C. \& Jungermann, K., eds) pp. 27-53, Plenum, New York.

91. Daniel, P. M. \& Pritchard, P. P. M. (1951) J. Physiol. 114, $538-$ 548.

92. Ungvary, G. \& Varga, B. (1971) Acta Physiol. Acad. Sci. Hung. $40,347-356$.

93. Reilly, F. D., McCuskey, R. S. \& Cilento, E. V. (1981) Microvasc. Res. 21, 103-109.

94. Greenway, C. V., Lawson, A. E. \& Mellander, S. (1967) J. Physiol. 192, $21-41$.

95. Gardemann, A. \& Jungermann, K. (1986) Hoppe Seyler Biol. Chem. 367, 559-566.

96. Ballé, C., Beuers, U. Engelhardt R. \& Jungermann, K. (1987) Eur. J. Biochem. 170, 193-199.

97. Beckh, K., Beuers, U., Engelhardt, R. \& K. Jungermann (1987) Biol. Chem. Hoppe Seyler 368, 379-386.

98. Athari, A. \& Jungermann, K. (1990) Biochem. Int. 20, 13-23.

99. Beckh, K., Fuchs, E., Ballé, C. \& Jungermann K. (1990) Biol. Chem. Hoppe Seyler 371, 153-158.

100. Sugiyama, Y. \& Ohta, H. (1990) Arch. Histol. Cytol. 53, $71-$ 80.

101. Miyashita, T., Takeda, A., Iwai, M. \& Shimazu, T. (1991) Eur. J. Biochem. 196, $37-42$. 
102. Brinkmann, A., Katz, N., Sasse, D. \& Jungermann, K. (1978) Hoppe-Seyler's Z. Physiol. Chem. 359, 1561-1571.

103. Iwai, M., Miyashita, T. \& Shimazu, T. (1991) Eur. J. Biochem. $200,69-74$.

104. Seseke, F., Gardemann, A. \& Jungermann, K. (1992) FEBS Lett., in the press.

105. Decker, K. (1985) Semin. Liver Dis. 5, 175-190.

106. Tran Thi, D. A., Häussinger, D., Gyufko, K. \& Decker, K. (1988) Biol. Chem. Hoppe Seyler 369, 65-68.

107. Vom Dahl, S., Wettstein, M., Gerok, W.\& Häussinger, D. (1990) Biochem. J. 270, 39-44.

108. Dieter, P., Altin, P. G., Decker, K. \& Bygrave, F. L. (1987) Eur. J. Biochem. 165, 455-460.

109. Dieter, P., Altin, J. G. \& Bygrave, F. L. (1987) FEBS Lett. 213, $174-178$.

110. Casteleijn, E., Kuiper, J., Van Rooij, H. C., Kamps, J. A., Koster, J. F. \& Van Berkel, T. J. (1988) J. Biol. Chem. 263, 6953-6955.

111. Buxton, D. B., Fisher, R. A., Briseno, D. L., Hanahan, D. J. \& Olson, M. S. (1987) Biochem. J. 243, 493-498.

112. Püschel, G. P., Oppermann, M., Muschol, W., Götze, O. \& Jungermann, K. (1989) FEBS Lett. 243, 83-87.

113. Muschol, W., Püschel, G. P., Hülsmann, M. \& Jungermann, K. (1991) Eur. J. Biochem. 196, 525-530.

114. Tran Thi, T. A., Gyufko, K., Häussinger, D. \& Decker, K. (1988) J. Hepatol. 6, 151-157.

115. Iwai, M. \& Jungermann, K. (1987) FEBS Lett. 221, 155-160.
116. Dieter, P., Schulze-Specking, A. \& Decker, K. (1989) Biol. Chem. Hoppe Seyler 370, 543-547.

117. Iwai, M., Gardemann, A., Püschel, G. P. \& Jungermann, K. (1988) Eur. J. Biochem. 175, 45-50.

118. Iwai, M. \& Jungermann, K. (1989) Eur. J. Biochem. 180, $273-$ 281 .

119. Häussinger, D., Stehle, T., Tran Thi, T. A., Decker, K. \& Gerok, W. (1987) Biol. Chem. Hoppe Seyler 368, 1509-1513.

120. Altin, J. G. \& Bygrave, F. L. (1988) Biochem. J. 249, 677-685.

121. Athari, A. \& Jungermann, K. (1989) Biochem. Biophys. Res. Commun. 163, 1235-1242.

122. Mine, T., Kojima, I. \& Ogata, E. (1990) Endocrinology 126, $2831-2836$

123. Kuiper, J., Zijlstra, F. J., Kamps, J. A. \& Van Berkel, T. J. (1989) Biochem. J. 262, 195-201.

124. Saez, J. C., Connor, J. A., Spray, D. C. \& Bennett, M. V. L. (1989) Proc. Natl Acad. Sci. USA 86, 2708-2712.

125. Dawson, W. (1970) Brit. J. Pharmacol. 39, 585.

126. Exton, J. H. (1987) Kidney Int. Suppl. 23, S68-\$81.

127. Exton, J. H. (1987) Diabetes Metab. Rev. 3, 163-183.

128. Püschel, G. P. \& Jungermann, K. (1988) Eur. J. Biochem. 175, $187-191$.

129. Van de Werve, G. \& Jeanrenaud, B. (1987) Diabetes Met. Rev. $3,47-78$.

130. Gardemann, A., Strulik, H. \& Jungermann, K. (1986) FEBS Lett. 202, 255-259. 